\title{
Aspectos relevantes do controle de perdas em sistemas públicos de abastecimento de água
}

\section{Relevant aspects of the control of losses in public water supply systems}

\section{INTRODUÇÃO}

O setor de saneamento no Brasil ainda luta para eliminar os déficits de atendimento com os serviços de água e esgoto. $O$ retrato atual mostra vergonhosos padrões sanitários para um país que se jacta de ser um dos grandes da economia mundial. A infraestrutura de abastecimento público de água avançou significativamente em relação ao atendimento com coleta e tratamento de esgotos, mas apresenta lacunas em algumas áreas urbanizadas e corre atrás da contínua expansão urbana.

Essa questão da expansão ainda em curso pode ser uma explicação de por que se dá menos importância às atividades de operação e manutenção dos serviços de infraestrutura urbana, em relação às obras de implantação dessa infraestrutura. Pode explicar, mas não é só isso: há que se agregar a lastimável predominância do valor político que se dá ao ato pontual do "construir", em detrimento do ato permanente do "operar e manter”, valor tão arraigado na cultura brasileira.

O abastecimento público de água é, desnecessário justificar, uma das mais importantes infraestruturas urbanas. É, essencialmente, uma estrutura linear, em que prevalecem as tubulações para a condução da água, desde a captação em um manancial até a entrega da água potável ao consumidor final, entremeada pelas instalações de tratamento, reservação e elevação ou redução de pressão.

A maior parte das tubulações encontra-se disposta no reticulado urbano, em todas as ruas, associadas ao trecho final da ligação ao cliente (ramal predial, com hidrômetro, para medição do consumo e faturamento), compondo o conjunto que se denomina “distribuição". É nessa parte do sistema

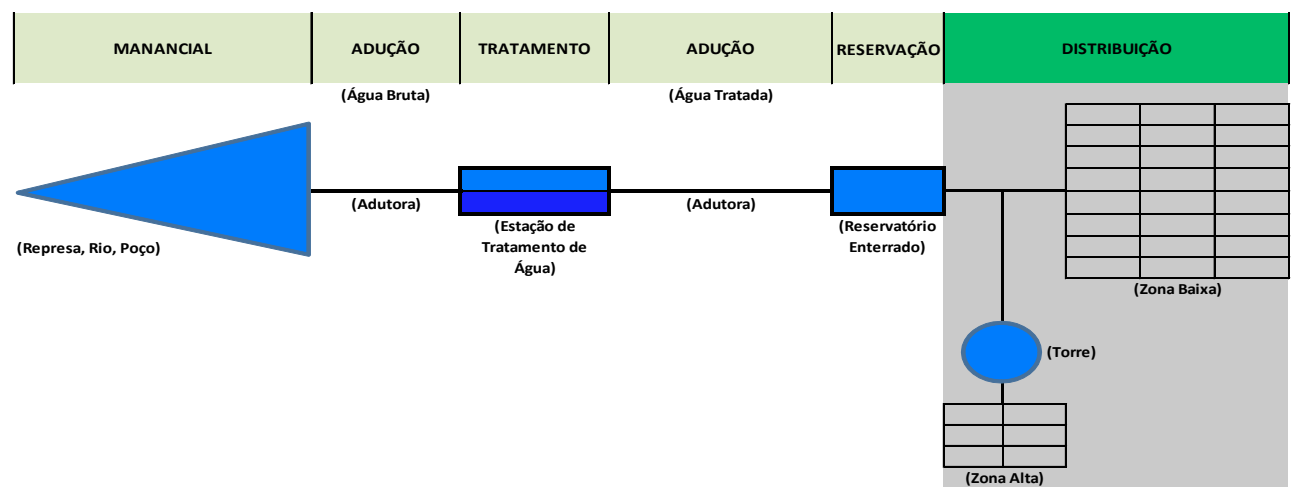

Figura 1 - Sistema de abastecimento de água.

Jairo Tardelli Filho - Engenheiro civil pela Escola Politécnica da Universidade de São Paulo (1977), Mestre em Recursos Hídricos (1987). Trabalhou na área de saneamento ambiental nas empresas estatais paulistas Emplasa, Cetesb e Sabesp. Foi Assessor da Diretoria de Controle da Poluição da RMSP (Cetesb) e Gerente de Departamento das áreas de Controle do Abastecimento e de Planejamento Integrado da Diretoria Metropolitana (Sabesp).

Email: jtftardelliauol.com.br 


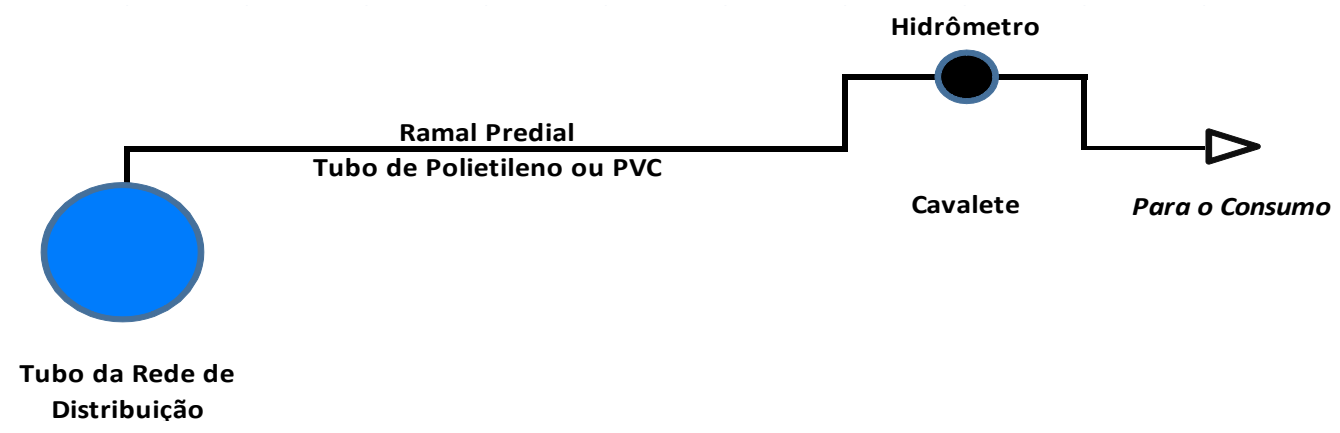

Figura 2 - Ramal predial de água.

de água, com seus zoneamentos piezométricos, que se concentrará este artigo. As Figuras 1 e 2 ilustram essas considerações.

\section{OPERAÇÃO E MANUTENÇÃO}

Há um entendimento generalizado de que "operar" um sistema de água é simplesmente abrir e fechar válvulas, ligar e desligar bombas e de que "manter" é somente reparar os problemas que surgem nas tubulações e equipamentos (manutenção corretiva).

Operar um sistema de distribuição de água é muito mais amplo do que o relatado e envolve, principalmente:

- ter cadastros técnicos e comerciais confiáveis (atualizados);

- medir as vazões na saída (ou entrada) de reservatórios setoriais e estações elevatórias e na entrada de áreas específicas das redes de distribuição, bem como pressões em pontos notáveis da rede e níveis em reservatórios;

- garantir a observância das variáveis operacionais aos padrões estabelecidos por norma;

- gerar indicadores de performance operacionais e respectivas análises gerenciais;

- elaborar relatórios analíticos e gerenciais de comportamento e tendências das variáveis operacionais medidas em todos os setores de abastecimento e zonas de pressão.
Manter um sistema de distribuição de água envolve, principalmente:

- implementar atividades de manutenção preditiva (inspeções e medições das estruturas e equipamentos em operação);

- implementar atividades de manutenção preventiva, a partir de análises das informações da manutenção preditiva e dos históricos de manutenção corretiva;

- gerar informações e relatórios gerenciais sobre as falhas do sistema, de forma a subsidiar as manutenções preditivas e preventivas, bem como as renovações estruturais requeridas;

- preparar esquemas de contingência e prover logística para o ágil reparo e retomada da operação normal, em casos de acidentes ou falhas.

É um campo notável da engenharia, pouco desenvolvido nos currículos das faculdades (mais afetos a projetos e obras, por assim dizer) e que se pode denominar "engenharia da operação", que se opõe ao empirismo e ao voluntarismo na operação e manutenção das redes de distribuição de água.

E o que isso tem a ver com "perdas" em sistemas de água? Tudo, pois a determinação das perdas e seu controle são a melhor forma de avaliar se as atividades de operação e manutenção do sistema de água estão bem conduzidas. Os números dos indicadores de perdas são uma medida da sua eficiência operacional. 


\section{PERDAS NAS REDES DE DISTRIBUIÇÃO DE ÁGUA}

Basicamente, as "perdas" representam a diferença entre o que se disponibilizou de água tratada à distribuição (macromedição) e o que se mediu nos hidrômetros dos clientes finais (micromedição). É senso comum imaginar que as perdas são motivadas exclusivamente pelos vazamentos nas tubulações, com a visão da água escorrendo pelas vias públicas. Se a perda fosse só isso, seria relativamente simples atuar no seu combate. Há vazamentos que não afloram à superfície e também outros fatores, que não têm nada a ver com vazamentos e integram aquela diferença: os erros ou submedições nos hidrômetros (e macromedidores) e as fraudes; aqui, portanto, a água é consumida, mas não é contabilizada pela companhia de água ou operadora.

Até o ano 2000, essa definição singela não era entendida da mesma maneira no mundo, causando distorções na compreensão e nas comparações entre os números e indicadores de perdas de cidades, regiões ou países distintos. Assim, a International Water Association (IWA) propôs uma estruturação na forma de balanço hídrico, que padronizou, de maneira clara e objetiva, os vários usos da água em um sistema e a identificação dos dois tipos de perda (ALEGRE, 2006):

- as reais, compostas pelos vazamentos nas tubulações e extravasamentos nos reservatórios (perdas físicas);

- as aparentes, compostas pelos erros de medição (submedição nos hidrômetros), fraudes e falhas no sistema comercial das empresas (perdas não físicas ou comerciais).

O Quadro 1 mostra o balanço hídrico da IWA ${ }^{1}$. Seu uso é quase generalizado no mundo todo (o Japão, por exemplo, tem outro entendimento dessa questão).

Algumas considerações importantes:

- desperdícios internos nos imóveis, após os hidrômetros, não constituem perdas, no campo da definição aqui exposta;

\footnotetext{
1 Como curiosidade, registre-se a tentativa feita por Sextus Julius Frontinus (95 d.C.) para avaliar a água perdida nos aquedutos de Roma. Ele utilizou o conceito de "balanço hídrico" entre as águas que entravam no sistema e as que saíam, mas falhou na metodologia, pois utilizava apenas a seção transversal dos fluxos, sem considerar a velocidade do escoamento (FRAUENDORFER, 2010).
}

Quadro 1 - Balanço hídrico - IWA.

\begin{tabular}{|c|c|c|c|c|}
\hline \multirow{8}{*}{ 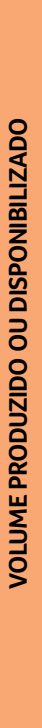 } & \multirow{3}{*}{ 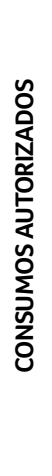 } & $\begin{array}{l}\text { Consumos } \\
\text { autorizados } \\
\text { faturados }\end{array}$ & Consumos medidos faturados (incluindo água exportada) & 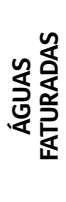 \\
\hline & & \multirow[b]{2}{*}{$\begin{array}{l}\text { Consumos } \\
\text { autorizados não } \\
\text { faturados }\end{array}$} & Consumos medidos não faturados (usos próprios, caminhões-pipa) & \multirow{7}{*}{ 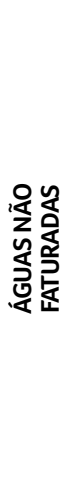 } \\
\hline & & & $\begin{array}{l}\text { Consumos não medidos não faturados (combate a incêndios, suprimento de } \\
\text { água em áreas irregulares) }\end{array}$ & \\
\hline & \multirow{5}{*}{ 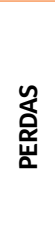 } & \multirow{2}{*}{$\begin{array}{l}\text { Perdas aparentes } \\
\text { (comerciais) }\end{array}$} & Falhas do sistema comercial & \\
\hline & & & Submedição dos hidrômetros & \\
\hline & & \multirow{3}{*}{ Perdas reais (físicas) } & Vazamentos nas adutoras e redes de distribuição & \\
\hline & & & Vazamentos nos ramais prediais & \\
\hline & & & Vazamentos e extravasamentos nos reservatórios setoriais e aquedutos & \\
\hline
\end{tabular}


- certos usos da água, não medidos e não faturados, entram no conceito de "águas não faturadas" e não de "perdas", pois são usos legítimos, como a água usada no combate a incêndios, os usos operacionais das companhias (lavagem de redes, por exemplo) e um tipo de uso que acontece muito nas grandes cidades brasileiras e de países em desenvolvimento, referente aos consumos não medidos e não faturados em áreas com ocupação urbana irregular;

- as perdas reais oneram os custos de produção e distribuição de água, enquanto as perdas aparentes estão associadas às vendas de água no varejo (preço por $\mathrm{m}^{3}$ cobrado dos clientes);

- a existência de caixas d'água domiciliares com válvula de boia potencializa a submedição dos hidrômetros e, portanto, é fator de aumento das perdas aparentes;

- as águas que escapam pelos vazamentos nas tubulações são fontes de recarga dos lençóis freáticos nas áreas urbanizadas; na região do Centro Expandido de São Paulo, estudos realizados mostraram que $45-60 \%$ da recarga do aquífero seria resultado das perdas reais de água nas redes de distribuição (consideradas $20 \%$ do total distribuído) e de esgotos nas redes de coleta (consideradas $5 \%$ do total coletado). 0 restante (55$40 \%)$ corresponderia à recarga natural (COMITÊ DA BACIA DO ALTO TIETÊ, 2009).

Se a valoração do total das perdas é relativamente simples, o mesmo não ocorre na determinação do seu rateio, ou seja, qual é o valor das perdas reais e qual é o valor das perdas aparentes. Para isso, há que se realizar ensaios de campo ou assumir hipóteses para determinar o valor de uma delas e, por diferença, resultar no valor da outra. É importante frisar que esse rateio varia de sistema para sistema, em função de condições locais das redes e dos hidrômetros, e da "cultura" de fraudes, cabendo, para cada caso, um diagnóstico para estimar esse rateio.
A Tabela 1 apresenta exemplos de rateio entre perdas reais e aparentes em algumas cidades ou regiões do mundo (EUROPEAN COMMISSION, 2015; TARDELLI FILHO, 2013; BETTIG, 2012; INSTITUTO ARAGONES DE ESTADISTICA, 2014).

Tabela 1 - Rateio perdas reais x perdas aparentes.

\begin{tabular}{|l|c|c|}
\hline \multirow{2}{*}{\multicolumn{1}{|c|}{ Local }} & \multicolumn{2}{c|}{ Rateio das perdas (\%) } \\
\cline { 2 - 3 } & Reais & Aparentes \\
\hline Salzburgo - Áustria & 92,3 & 7,7 \\
\hline Região de Flandres - Bélgica & 87,5 & 12,5 \\
\hline Pula-Croácia & 89,7 & 10,3 \\
\hline Lemesos-Chipre & 83,6 & 16,4 \\
\hline Odense-Dinamarca & 97,1 & 2,9 \\
\hline Bordeaux-França & 90,4 & 9,6 \\
\hline Munique-Alemanha & 85,3 & 14,7 \\
\hline Regio Emilia-Itália & 77,1 & 22,9 \\
\hline Malta & 30,1 & 69,9 \\
\hline Buenos Aires-Argentina & 91,0 & 9,0 \\
\hline Madrid-Espanha & 33,0 & 67,0 \\
\hline São Paulo-Brasil & 67,0 & 33,0 \\
\hline
\end{tabular}

Nos episódios de crise hídrica, as perdas reais são as que mais requerem atenção nas ações de redução de perdas, embora não deva ser esquecido que o combate às perdas aparentes também pode ter reflexos diretos na produção de água, na medida em que cerceia os desperdícios e o consumo fraudulento de água.

Não existe "perda zero" em sistemas de abastecimento de água! Por mais cuidados tomados e esforços realizados, sempre haverá um remanescente valor de perdas no sistema ("perda inevitável”). Outro ponto é que, se não forem feitas, regularmente, ações de combate às perdas, estas irão gradativamente aumentar no sistema (conceito de "crescimento natural das perdas").

\section{INDICADORES DE PERDAS}

Os principais indicadores utilizados para avaliar e acompanhar as perdas em sistemas de distribuição de água são: 
- Indicador Percentual (IP): é a relação entre os volumes de perdas totais em um período (geralmente anual) e os volumes de água produzidos ou disponibilizados à distribuição;

- Indicador Técnico (IT), em L/ligação.dia: é a relação entre os volumes totais perdidos em um período (geralmente anual) e o número de ligações ativas de água;

- Índice de Vazamentos da Infraestrutura (IVI), adimensional: é a relação entre o volume de perdas reais e o volume de perdas reais inevitáveis para o sistema em questão (base anual); traduz o quanto o sistema está distante do volume de perdas que é, tecnicamente, possível de ser atingido;

- Índice de Perdas Aparentes (IPA), adimensional: é o mesmo conceito do IVI, sendo a relação entre o volume de perdas aparentes e um fator equivalente a $5 \%$ do volume micromedido na cidade ou região (base anual), denominado perda aparente de referência. Essa formulação pressupõe sistemas sem caixas d'água domiciliares: quando há predomínio de caixas d'água domiciliares, é impossível atingir IPA = 1; portanto, há que se conviver com valores maiores de IPA.

Evolutivamente, verifica-se que tem sido sugerido o indicador "volume anual perdido" em um sistema como adequado à definição de metas nos programas de redução de perdas (EUROPEAN COMMISSION, 2015).

Não há indicador perfeito! No entanto, o mais fácil de ser entendido por todos é o "mais imperfeito" deles: o percentual. A IWA não recomenda seu uso, pelas distorções que ocorrem na comparação entre sistemas distintos (todavia, ainda é muito utilizado...).

\section{COMBATE ÀS PERDAS}

A causa principal das perdas reais é, indubitavelmente, a qualidade da infraestrutura. Outros fatores podem aumentar os vazamentos, entre os quais, a pressão de serviço é o mais significativo, seguido da qualidade da manutenção, das condições de assentamento das tubulações, do tráfego etc. No caso das perdas aparentes, as limitações técnico-operacionais dos medidores são preponderantes, realçadas pela idade de instalação na rede e pelas variações do fluxo d'água neles (especialmente nas vazões muito reduzidas).

As ações básicas para o combate às perdas reais são:

- gerenciamento de pressões, em que, no contexto da setorização da rede de distribuição, se busca operar com pressões de serviço adequadas, complementando com a utilização de Válvulas Redutoras de Pressão (VRPs) em áreas mais baixas ou boosters em pontos mais altos da rede;

- controle ativo de vazamentos, que se dedica a encontrar os vazamentos não visíveis nas tubulações por meio de técnicas acústicas de detecção (contrapõe-se ao "controle passivo", que repara apenas os vazamentos que afloram à superfície do terreno);

- reparo dos vazamentos visíveis e não visíveis detectados, com agilidade e qualidade na execução;

- renovação da infraestrutura, substituindo as tubulações (redes e ramais) que estão com maior incidência de vazamentos.

Para as perdas aparentes, as principais ações são:

- substituição periódica dos hidrômetros (preventiva) e imediata dos hidrômetros quebrados (corretiva);

- combate às fraudes, a partir de denúncias, análises de variações atípicas de consumo ou quaisquer outros indícios ou evidências;

- aprimoramento da gestão comercial das companhias (cadastros e sistemas comerciais).

A eficácia dessas ações pressupõe:

- a existência de cadastros técnicos (redes e ramais) e comerciais atualizados; 
- a medição dos volumes nos setores e subsetores do sistema (macromedição) e hidrometração dos consumidores (micromedição);

- a compartimentação estanque dos setores de abastecimento e subsetores (zonas de pressão e Distritos de Medição e Controle - DMCs).

O que se observa é que as precondições e as próprias ações requeridas não se configuram como um leque amplo de possibilidades de atuação! Mesmo assim, em nome da maior eficácia e da parcimônia na aplicação dos recursos, há que se ter bons diagnósticos operacionais para direcionar as ações mais apropriadas para cada área.

O Quadro 2 sintetiza as ações requeridas para cada tipo de problema gerador de perdas de água na rede de distribuição.

Quadro 2 - Soluções para os problemas de perdas.

\begin{tabular}{|c|c|c|}
\hline Problema & Intervenção Preventiva ou Corretiva & Suporte \\
\hline \multicolumn{3}{|c|}{ INFORMAÇÃO - DIAGNÓSTICO - GESTÃO } \\
\hline $\begin{array}{l}\text { Cadastros técnico e/ou comercial } \\
\text { desatualizados }\end{array}$ & $\begin{array}{l}\text { Atualização cadastral, definição de fluxos e } \\
\text { responsabilidades }\end{array}$ & Plantas cadastrais, croquis, as built, GIS \\
\hline Setorização inexistente ou precária & $\begin{array}{l}\text { Compartimentação piezométrica ou operacional } \\
\text { (DMCs) }\end{array}$ & Cadastro técnico, GIS, modelagem \\
\hline Falta de estanqueidade & $\begin{array}{l}\text { Eliminação dos fluxos entre setores ou zonas } \\
\text { piezométricas }\end{array}$ & Cadastro técnico, GIS, ensaios em campo \\
\hline Macromedição inexistente ou deficiente & $\begin{array}{l}\text { Instalação de macromedidores, substituição ou } \\
\text { adequação de macromedidores, calibração periódica }\end{array}$ & Cadastro técnico, ensaios de pitometria \\
\hline Inexistência de hidrômetro & Instalação de hidrômetro & Cadastro comercial \\
\hline Supervisão inexistente & $\begin{array}{l}\text { Monitoramento (nível, pressão, vazão) de pontos } \\
\text { estratégicos ou críticos da rede }\end{array}$ & $\begin{array}{l}\text { Equipamentos registradores, ensaios pitométricos, } \\
\text { telemetria }\end{array}$ \\
\hline $\begin{array}{l}\text { Informações inexistentes ou } \\
\text { desorganizadas }\end{array}$ & Sistema informatizado e atualizado & Monitoramento, GIS, indicadores \\
\hline Inexistência de diagnóstico & Elaboração de diagnóstico operacional e comercial & $\begin{array}{l}\text { Ensaios em campo, análises de dados, balanço } \\
\text { hídrico, indicadores }\end{array}$ \\
\hline $\begin{array}{l}\text { Gestão operacional ou comercial } \\
\text { inadequadas }\end{array}$ & $\begin{array}{l}\text { Elaboração de balanços hídricos, sistemas } \\
\text { informatizados, relatórios gerenciais, definição de } \\
\text { metas }\end{array}$ & Indicadores, tendências, referenciais comparativos \\
\hline \multicolumn{3}{|c|}{ QUALIFICAÇÃO - MATERIAIS E MÃO DE OBRA } \\
\hline Materiais e ferramentas inadequados & $\begin{array}{l}\text { Registro de falhas, melhoria das especificações, maior } \\
\text { rigor nas inspeções }\end{array}$ & Especificações, normas \\
\hline Mão de obra despreparada & Treinamento, certificação profissional & $\begin{array}{l}\text { Centros de treinamento, sistema de qualificação e } \\
\text { certificação }\end{array}$ \\
\hline Execução mal feita dos serviços & Fiscalização, controle tecnológico & Especificações, normas \\
\hline Problemas com subcontratadas & Fiscalização, treinamento, certificação profissional & Contratos, especificações \\
\hline $\begin{array}{l}\text { Problemas no recebimento de obras e } \\
\text { serviços }\end{array}$ & $\begin{array}{l}\text { Fiscalização, ensaios hidrostáticos, análises de } \\
\text { amostras }\end{array}$ & Contratos, especificações, normas \\
\hline
\end{tabular}

\begin{tabular}{|c|c|c|}
\hline \multicolumn{3}{|c|}{ COMBATE ÀS PERDAS REAIS } \\
\hline Pressão alta & Setorização, instalação de VRPs & Cadastro técnico, GIS, monitoramento, modelagem \\
\hline Pressão baixa nos pontos mais elevados & Instalação de boosters (rotação variável) & Cadastro técnico, GIS, monitoramento, modelagem \\
\hline $\begin{array}{l}\text { Grande variação da pressão ao longo do } \\
\text { dia }\end{array}$ & $\begin{array}{l}\text { Substituição de redes, instalação de VRPs } \\
\text { "inteligentes" }\end{array}$ & Cadastro técnico, GIS, monitoramento, modelagem \\
\hline Vazamentos visíveis nas redes & $\begin{array}{l}\text { Reparo ágil, redução de pressão, substituição de } \\
\text { tubulação }\end{array}$ & Telefone 195, mapeamento, indicadores, modelagem \\
\hline Vazamentos visíveis nos ramais & Substituição ágil do ramal, redução de pressão & Telefone 195, mapeamento, indicadores, modelagem \\
\hline Vazamentos não visíveis nas redes & $\begin{array}{l}\text { Pesquisa de vazamentos, reparo, redução de pressão, } \\
\text { substituição de tubulação }\end{array}$ & Mapeamento, indicadores, modelagem \\
\hline Vazamentos não visíveis nos ramais & $\begin{array}{l}\text { Pesquisa de vazamentos, substituição do ramal, } \\
\text { redução de pressão }\end{array}$ & Mapeamento, indicadores, modelagem \\
\hline Vazamentos inerentes nas redes & Substituição de redes, redução de pressão & Ensaio de campo, modelagem \\
\hline Vazamentos inerentes nos ramais & $\begin{array}{l}\text { Substituição do ramal, diminuição de juntas, redução } \\
\text { de pressão }\end{array}$ & Ensaio de campo \\
\hline Extravasamento de reservatórios & Controle de nível d'água & Monitoramento, telemetria, telecomando \\
\hline
\end{tabular}


Quadro 2 - Soluções para os problemas de perdas (continuação)

\begin{tabular}{|l|l|l|}
\hline \multicolumn{2}{|c|}{ COMBATE ÀS PERDAS APARENTES } \\
\hline Hidrômetro quebrado ou com problemas & Troca corretiva & Telefone 195, cadastro comercial \\
\hline Submedição elevada & $\begin{array}{l}\text { Troca preventiva otimizada, desinclinação, } \\
\text { desenvolvimento tecnológico dos hidrômetros }\end{array}$ & Gestão comercial, ensaios de bancada, normas \\
\hline Fraudes e ligações clandestinas & Inspeção e penalização & Canal de denúncia, gestão comercial e dos consumos \\
\hline Falhas do sistema comercial & $\begin{array}{l}\text { Auditorias, melhorias no sistema, modernização de } \\
\text { processos }\end{array}$ & Gestão comercial \\
\hline Gestão deficiente dos grandes clientes & $\begin{array}{l}\text { Adequação de medidores, troca preventiva mais } \\
\text { frequente }\end{array}$ & Telemetria, gestão comercial \\
\hline
\end{tabular}

\section{DIAGNÓSTICOS}

Os diagnósticos operacionais de um sistema de distribuição de água podem ser feitos em vários níveis.

Num primeiro nível, envolvem diversos indicadores operacionais e sua comparação com padrões internacionais (ou nacionais), de forma a enquadrá-los nas faixas situacionais correspondentes. Nesse sentido, o quadro recentemente desenvolvido pela European Commission (2015), adaptado e ampliado pelo autor, dá uma contextualização do sistema em questão (Quadro 3). Sua aplicação por qualquer companhia ou operadora de água serve para orientar as ações ou mesmo uma estruturação de ações no corpo de um Programa de Controle de Perdas.

Por sua vez, o Quadro 4, desenvolvido pelo Banco Internacional de Reconstrução e Desenvolvimento (BIRD) (KINGDOM, 2006), dá base para o enquadramento situacional, com vistas às perspectivas futuras (definição de metas) para as perdas reais, em que entram em cena a caracterização do país em termos de nível de desenvolvimento e as pressões médias reinantes.

Outros tipos de diagnóstico operacional envolvem:

- ensaios de campo, para a determinação das perdas e das causas predominantes na área (pitometria, registradores de dados);

- levantamento de indicadores específicos, em áreas geralmente menores, para composição de um "mosaico" em um setor ou num conjun- to de setores, identificando aqueles mais críticos e possibilitando a priorização das ações. No caso de vazamentos em redes e ramais, a utilização dos referenciais mundiais da IWA (13 vazamentos $/ 100 \mathrm{~km}$.ano para redes e 3 vazamentos/1.000 ligações.ano para ramais) constitui ferramenta vigorosa na priorização das ações de renovação das tubulações ou na orientação das pesquisas de vazamentos não visíveis (SILVA JR, 2015).

No contexto do diagnóstico operacional, vale destacar um ponto importante, que se refere à caracterização dos vazamentos. Existem três tipos de vazamento:

- os visíveis (vazões geralmente mais altas), que afloram à superfície das ruas;

- os não visíveis (predominantemente médias vazões), que são possíveis de ser detectados por meio das pesquisas acústicas, atividade rotineira nas companhias ou operadoras de água;

- os não visíveis (baixas vazões), não detectáveis pelos equipamentos de pesquisa acústica, denominados "vazamentos inerentes".

Infelizmente, os vazamentos visíveis representam pouco na totalização dos volumes perdidos; a grande maioria dos vazamentos nas redes e ramais não aflora à superfície! Por sua vez, os ramais prediais são os pontos mais frágeis da rede de distribuição, verificando-se a ocorrência do maior número de falhas e do maior volume perdido. 
Quadro 3 - Informações de contexto

\begin{tabular}{|c|c|c|c|c|c|c|}
\hline \multirow{2}{*}{ PARÂMETRO } & \multirow{2}{*}{ UNIDADE DE MEDIDA } & \multicolumn{5}{|c|}{ DESCRIÇÃO DO PORTE DO SISTEMA } \\
\hline & & Muito Pequeno & Pequeno & Médio & Grande & Muito Grande \\
\hline Ligações & Número & $<3$ mil & 3 mil a 30 mil & 30 mil a 300 mil & 300 mil a 3 milhões & $>3$ milhões \\
\hline Densidade de Ligações & $N^{\circ}$ por km de rede & $<20$ & 20 a 30 & 30 a 50 & 50 a 70 & $>70$ \\
\hline $\begin{array}{l}\text { Comprimento Médio de } \\
\text { Rede }\end{array}$ & Metros por ligação & $<4$ & 4 a 8 & 8 a 12 & 12 a 16 & $>16$ \\
\hline \multirow{2}{*}{$\begin{array}{l}\text { PARÂMETRO OU } \\
\text { INFORMAÇÃO DE } \\
\text { CONTEXTO }\end{array}$} & \multirow{2}{*}{ UNIDADE DE MEDIDA } & \multicolumn{5}{|c|}{ INDICADOR DE PERFORMANCE OU DESCRIÇÃO DA INFORMAÇÃO DE CONTEXTO } \\
\hline & & Muito Baixo & Baixo & Moderado & Alto & Muito Alto \\
\hline Pressão Média do Sistema & mca & $<30$ & 30 a 40 & 40 a 50 & 50 a 60 & $>60$ \\
\hline $\begin{array}{l}\text { Vazamentos Visíveis ou Não } \\
\text { Visíveis em Rede }\end{array}$ & $\begin{array}{l}\text { Vazamentos } / 100 \mathrm{~km} . \\
\text { ano }\end{array}$ & $<7$ & 7 a 10 & 10 a 15 & 15 a 20 & $>20$ \\
\hline $\begin{array}{l}\text { Rede - Tempo Médio para o } \\
\text { Reparo de Vazamento }\end{array}$ & Dia & $<1$ & 1 a 2 & 2 a 4 & 4 a 8 & $>8$ \\
\hline $\begin{array}{l}\text { Vazamentos Visíveis ou Não } \\
\text { Visíveis em Ramal }\end{array}$ & $\begin{array}{l}\text { Reparos } / 1.000 \text { ramais. } \\
\text { ano }\end{array}$ & $<3$ & $3 a 4$ & 4 a 7 & 7 a 10 & $>10$ \\
\hline $\begin{array}{l}\text { Ramal - Tempo Médio para } \\
\text { o Reparo ou Troca }\end{array}$ & Dia & $<2$ & 2 a 4 & 4 a 8 & 8 a 16 & $>16$ \\
\hline $\begin{array}{l}\text { Controle Ativo de } \\
\text { Vazamentos }\end{array}$ & $\%$ rede pesquisada.ano & $<10 \%$ & 10 a $30 \%$ & 30 a $70 \%$ & 70 a $90 \%$ & $>90 \%$ \\
\hline Renovação de Redes & $\begin{array}{l}\text { \% extensão de rede. } \\
\text { ano }\end{array}$ & $<0,3 \%$ & 0,3 a $0,5 \%$ & 0,5 a $1,5 \%$ & 1,5 a $2,0 \%$ & $>2,0 \%$ \\
\hline Macromedição & $\begin{array}{l}\text { \% volumes } \\
\text { disponibilizados }\end{array}$ & $<70 \%$ & 70 a $80 \%$ & 80 a $90 \%$ & 90 a $98 \%$ & $>98 \%$ \\
\hline $\begin{array}{l}\text { Calibração dos } \\
\text { Macromedidores }\end{array}$ & $\begin{array}{l}\text { \% medidores } \\
\text { calibrados }\end{array}$ & $<70 \%$ & 70 a $80 \%$ & 80 a $90 \%$ & 90 a $98 \%$ & $>98 \%$ \\
\hline Hidrometração & \% ligações ativas & $<70 \%$ & 70 a $80 \%$ & 80 a $90 \%$ & 90 a $98 \%$ & $>98 \%$ \\
\hline $\begin{array}{l}\text { Idade Média dos } \\
\text { Hidrômetros }\end{array}$ & Ano & $<3$ & 3 a 5 & 5 a 8 & 8 a 10 & $>10$ \\
\hline Constatação de Fraude & \% das inspeções & $<10 \%$ & 10 a $20 \%$ & 20 a $30 \%$ & 30 a $40 \%$ & $>40 \%$ \\
\hline \multirow{2}{*}{ INDICADOR } & \multirow{2}{*}{ UNIDADE DE MEDIDA } & \multicolumn{5}{|c|}{ INDICADOR DE PERFORMANCE } \\
\hline & & Muito Baixo & Baixo & Moderado & Alto & Muito Alto \\
\hline $\begin{array}{l}\text { Índice de Vazamentos da } \\
\text { Infraestrutura - IVI }\end{array}$ & Adimensional & $<1,5$ & 1,5 a 2,0 & 2,0 a $4,0 *$ & $4,0 *$ a $8,0 *$ & $>8,0^{*}$ \\
\hline $\begin{array}{l}\text { Índice de Perda Aparente } \\
- \text { IPA }^{* * *}\end{array}$ & Adimensional & $<2,0^{*}$ & $2,0 *$ a $3,0 *$ & $3,0 *$ a $5,0^{*}$ & $5,0 *$ a $8,0 *$ & $>8,0^{*}$ \\
\hline $\begin{array}{l}\text { Índice de Perdas Totais na } \\
\text { Distribuição - IPD }\end{array}$ & L/ligação.dia & $<100$ & 100 a 150 & 150 a 250 & 250 a 500 & $>500$ \\
\hline $\begin{array}{l}\text { Índice de Águas Não } \\
\text { Faturadas - IANF }\end{array}$ & $\%$ & $<15 \%$ & 15 a $25 \%$ & 25 a $35 \%$ & 35 a $45 \%$ & $>45 \%$ \\
\hline \multicolumn{7}{|c|}{ * Limites para esses parâmetros são provisórios e sujeitos a posterior checagem ou revisão } \\
\hline
\end{tabular}

Quadro 4 - Sistema de bandas do BIRD.

\begin{tabular}{|c|c|c|c|c|c|c|c|}
\hline \multirow{2}{*}{\multicolumn{2}{|c|}{ Categoria de Performance Técnica }} & \multirow{3}{*}{$\begin{array}{c}\text { IVI } \\
10 \text { mca } \\
1-2\end{array}$} & \multicolumn{5}{|c|}{$\begin{array}{l}\text { Perdas Reais, em L/ramal.dia, quando o sistema está pressurizado, com } \\
\text { pressão média de: }\end{array}$} \\
\hline & & & \multirow[t]{2}{*}{$20 \mathrm{mca}$} & \multirow{2}{*}{$\begin{array}{l}30 \text { mca } \\
<50\end{array}$} & \multirow{2}{*}{$\begin{array}{l}40 \text { mca } \\
<75\end{array}$} & \multirow{2}{*}{$\begin{array}{c}50 \text { mca } \\
<100\end{array}$} & \multirow[b]{2}{*}{$<125$} \\
\hline \multirow{4}{*}{ Países Desenvolvidos } & A & & & & & & \\
\hline & $\mathrm{B}$ & $2-4$ & & $50-100$ & $75-150$ & $100-200$ & $125-250$ \\
\hline & $\mathrm{C}$ & $4-8$ & & $100-200$ & $150-300$ & $200-400$ & $250-500$ \\
\hline & $\mathrm{D}$ & $>8$ & & $>200$ & $>300$ & $>400$ & $>500$ \\
\hline \multirow{4}{*}{ Países em Desenvolvimento } & A & $1-4$ & $<50$ & $<100$ & $<150$ & $<200$ & $<250$ \\
\hline & $\mathrm{B}$ & $4-8$ & $50-100$ & $100-200$ & $150-300$ & $200-400$ & $250-500$ \\
\hline & $\mathrm{C}$ & $8-16$ & $100-200$ & $200-400$ & $300-600$ & $400-800$ & $500-1000$ \\
\hline & $\mathrm{D}$ & $>16$ & $>200$ & $>400$ & $>600$ & $>800$ & $>1000$ \\
\hline \multicolumn{8}{|c|}{$\begin{array}{l}\text { A - Redução de perda adicional pode não ser econômica, a não ser que haja insuficiência de abastecimento; são necessárias análises mais criteriosas para } \\
\text { identificar o custo de melhoria efetiva }\end{array}$} \\
\hline \multicolumn{8}{|c|}{$\begin{array}{l}\text { B - Potencial para melhorias significativas; considerar o gerenciamento de pressão, práticas melhores de controle ativo de vazamentos e uma melhor } \\
\text { manutenção da rede }\end{array}$} \\
\hline \multicolumn{8}{|c|}{$\begin{array}{l}\text { C - Registro deficiente de vazamentos; tolerável somente se a água é abundante e barata; mesmo assim, analise o nível e a natureza dos vazamentos e } \\
\text { intensifique os esforços para a redução dos vazamentos }\end{array}$} \\
\hline
\end{tabular}




\section{ESTRUTURAÇÕES E CONTINUIDADE DAS AÇÕES}

$O$ combate às perdas nas companhias ou operadoras de água normalmente é estruturado na forma de um programa, composto por um rol de ações operacionais e estruturais. Tal programa deve ter como suporte análises específicas ou diagnósticos que definiram ser aquelas ações, naqueles lugares e naqueles quantitativos, as que irão proporcionar os melhores resultados na queda dos indicadores de perdas ao longo dos anos, até o horizonte de planejamento estipulado.

Uma dificuldade ainda existente na formulação dos Programas de Controle de Perdas é a avaliação dos resultados decorrentes daquele conjunto de ações proposto: se todas as ações programadas forem feitas no tempo estipulado, para quanto cairá o índice de perdas, ou seja, a meta proposta será atingida? Infelizmente, dadas as variáveis e as incertezas agregadas, os modelos conceituais existentes ainda não fornecem essas respostas com algum nível de precisão, fragilizando o processo de planejamento. A melhor forma de superar essa dificuldade é, assumindo algumas hipóteses e definindo as metas, fazer o acompanhamento regular dos resultados e, no fim do ano, após análises técnicas, efetuar ajustes nas ações ou mesmo reavaliação das metas.

Até "quanto" se deve perseguir a redução de perdas? Foi definido anteriormente o "limite técnico" para as perdas em um dado local (perdas "inevitáveis"), mas existe outro limite, quase sempre acima daquele, que é o "limite econômico", ou seja, há um ponto em que os custos para reduzir as perdas (no caso deste exemplo, as reais) superam os custos de produção e distribuição de água (ou os custos marginais para o desenvolvimento de um novo sistema produtor de água). Não é um cálculo simples e é bastante dependente de condicionantes regionais.

A experiência observada na implementação e operacionalização de Programas de Combate às Perdas mostra que nos primeiros anos os resulta- dos são animadores; depois, a cada ano que passa, são mais lentos e as ações requeridas ficam mais caras (incremento da atividade de renovação de infraestrutura). Um bom exemplo relativo aos "tempos" é o caso de Tóquio (SHIMOMURA, 2013), em que o indicador de perdas ${ }^{2}$ caiu de $80 \%$ para $20 \%$ em dez anos e de $20 \%$ para $3 \%$ em 60 anos!

Outro exemplo, de alguma forma associado ao que foi descrito no parágrafo anterior, é um programa que vinha sendo bem conduzido, com resultados favoráveis, mas que, por alguma contingência financeira ou administrativa da companhia, teve descontinuidade em algumas ações importantes. Constata-se que, em apenas um ano ou fração disso, se perde o trabalho de vários anos, gerando desgastes e desânimos nas equipes operacionais e gerenciais.

Desses fatos, podem-se extrair as seguintes lições:

- o combate às perdas não deve ser uma ação esporádica, pois os eventuais resultados positivos, se conseguidos em curto prazo, não se manterão;

- os Programas de Controle de Perdas têm, obrigatoriamente, um caráter de persistência e permanência, com planejamento, execução e gestão rigorosos.

Pode parecer, à primeira vista, que a formatação de um Programa de Controle de Perdas deve requerer bases tecnológicas, ferramentais e logísticas sofisticadas. Esse tipo de pensamento parece pressupor, também, que atividades de controle de perdas dizem respeito apenas às grandes companhias de saneamento. Isso só desestimula a percepção de que o que se propõe é a adequada operação e a manutenção dos sistemas de água, o que vale para grandes, médias e pequenas empresas na prestação de serviços de abastecimento de água à população, independentemente do ferramental utilizado. Imprescindível, nesse contexto, é contar com mão de obra treinada e compromis-

\footnotetext{
2 O indicador de perdas no Japão, pelo conceito específico lá adotado, praticamente representa apenas as perdas reais.
} 
sada, além de materiais qualificados, de forma a garantir a permanência dos resultados, eliminar retrabalhos e evitar desperdícios de recursos.

Em vista disso, a melhor forma de avançar nessa meIhoria operacional é trabalhar de forma gradual, ca- librando os passos e mudando de patamar à medida que as condições técnicas e econômico-financeiras assim o permitirem. As propostas contidas no Quadro 5 materializam essa gradualidade das ações de combate às perdas em qualquer companhia ou operadora de água (RODRIGUES DA COSTA, 2013).

Quadro 5 - Escalonamento das intervenções.

\begin{tabular}{|c|c|c|c|}
\hline Ação & Mínimo & Razoável & Desejável \\
\hline Cadastro Técnico & $\begin{array}{l}\text { Plantas cadastrais com a localização } \\
\text { das redes de distribuição e outras } \\
\text { informações básicas, como diâmetro, } \\
\text { extensão, idade e topografia. } \\
\text { Informações de campo, como limite } \\
\text { de setor, interligações, localização de } \\
\text { boosters e VRPs. }\end{array}$ & $\begin{array}{l}\text { Informações básicas confiáveis, com } \\
\text { definição dos setores de abastecimento e } \\
\text { zonas de pressão. } \\
\text { Incluir no processo a sistemática de } \\
\text { atualização cadastral para eliminação de } \\
\text { inconsistências. }\end{array}$ & $\begin{array}{l}\text { Informações georreferenciadas (GIS) para } \\
\text { toda a malha de distribuição, contendo } \\
\text { todos os setores de abastecimento, zonas } \\
\text { de pressão, DMCs e Distritos de Manobra } \\
\text { cadastrados. } \\
\text { Correlação do cadastro técnico com } \\
\text { sistemas operacionais e de manutenção, } \\
\text { propiciando a geração de mapas } \\
\text { temáticos e exportação de dados para } \\
\text { elaboração de modelos hidráulicos. }\end{array}$ \\
\hline Macromedição & $\begin{array}{l}\text { Macromedição nos setores de } \\
\text { abastecimento (reservatórios, derivação } \\
\text { em marcha), com macromedidor } \\
\text { dimensionado de acordo com a faixa de } \\
\text { vazão e aferido. }\end{array}$ & $\begin{array}{l}\text { Macromedidores instalados nas alças } \\
\text { das redes de distribuição, possibilitando o } \\
\text { controle da vazão mínima noturna. } \\
\text { Implantar programa de aferição } \\
\text { sistemática dos macromedidores. }\end{array}$ & $\begin{array}{l}\text { Monitoramento contínuo do sistema de } \\
\text { macromedição totalmente telemetrizado. } \\
\text { Setores subdivididos em DMCs } \\
\text { macromedidos e telemetrizados, } \\
\text { propiciando o monitoramento contínuo } \\
\text { da vazão. } \\
\text { Utilização de cartas de controle (CEP), no } \\
\text { monitoramento das vazões. }\end{array}$ \\
\hline $\begin{array}{c}\text { Gerenciamento de } \\
\text { Pressão }\end{array}$ & $\begin{array}{l}\text { Garantia da pressão mínima nos pontos } \\
\text { críticos de abastecimento. } \\
\text { Instalação de VRPs, possibilitando a } \\
\text { equalização de pressão principalmente } \\
\text { nos horários de maior consumo. }\end{array}$ & $\begin{array}{l}\text { Instalação de VRPs com controladores } \\
\text { eletrônicos que possibilitam a } \\
\text { equalização de pressão de acordo com a } \\
\text { variação de consumo. } \\
\text { Implantar o gerenciamento de pressão } \\
\text { em sistemas de bombeamento, por } \\
\text { intermédio da utilização de inversores de } \\
\text { frequência. } \\
\text { Monitoramento dos sistemas de } \\
\text { bombeamento, VRPs e pontos críticos. }\end{array}$ & $\begin{array}{l}\text { Implantação de estudos de setorização, } \\
\text { para equalização de pressão. } \\
\text { Monitoramento e controle de todos os } \\
\text { equipamentos (boosters e VRPs) e pontos } \\
\text { críticos de abastecimento. } \\
\text { Utilização de cartas de controle (CEP), no } \\
\text { monitoramento das pressões. }\end{array}$ \\
\hline $\begin{array}{l}\text { Controle Ativo de } \\
\text { Vazamentos }\end{array}$ & $\begin{array}{l}\text { Campanha de pesquisa de vazamentos, } \\
\text { com equipe capacitada e engajada. } \\
\text { Pesquisas de vazamentos não visíveis no } \\
\text { período noturno. }\end{array}$ & $\begin{array}{l}\text { Estudo criterioso para a priorização de } \\
\text { áreas com utilização de mapas temáticos } \\
\text { e vazão mínima noturna. } \\
\text { Tecnologias de pesquisa de vazamentos } \\
\text { adequadas a cada situação. } \\
\text { Controle de produtividade das equipes de } \\
\text { pesquisa. }\end{array}$ & $\begin{array}{l}\text { Utilização de indicadores de performance } \\
\text { por áreas de pesquisa- carta de controle. } \\
\text { Exigência de certificação profissional das } \\
\text { equipes de pesquisa. } \\
\text { Ação de pesquisa de vazamento conjunta, } \\
\text { com a renovação de estrutura e controle } \\
\text { de pressão. }\end{array}$ \\
\hline $\begin{array}{l}\text { Agilidade e Qualidade } \\
\text { dos Reparos }\end{array}$ & $\begin{array}{l}\text { Canal de atendimento telefônico } \\
\text { para reclamações e comunicação de } \\
\text { vazamentos. } \\
\text { Prazo para o reparo compatível com a } \\
\text { realidade da empresa. } \\
\text { Forma de atuaçã̃o diferenciada por } \\
\text { modalidade (ramal - rede). }\end{array}$ & $\begin{array}{l}\text { Central de atendimento telefônico } \\
\text { adequadamente dimensionada. } \\
\text { Equipes dimensionadas e capacitadas } \\
\text { para execução dos vazamentos com } \\
\text { qualidade e agilidade. } \\
\text { Implantação do registro de falhas, para } \\
\text { diminuição de reincidências. }\end{array}$ & $\begin{array}{l}\text { Sistemas informatizados e integrados } \\
\text { para acatamento, programação e } \\
\text { controle da execução dos vazamentos. } \\
\text { Controle tecnológico dos serviços } \\
\text { executados. } \\
\text { Exigência de certificação profissional para } \\
\text { a execução dos serviços. }\end{array}$ \\
\hline $\begin{array}{l}\text { Gerenciamento da } \\
\text { Infraestrutura }\end{array}$ & $\begin{array}{l}\text { Garantia da qualidade dos materiais, } \\
\text { ferramentas e equipamentos. } \\
\text { Garantia da qualidade da mão de obra e } \\
\text { da implantação da infraestrutura. } \\
\text { Análise do histórico de problemas e } \\
\text { renovação da infraestrutura em pontos } \\
\text { críticos. }\end{array}$ & $\begin{array}{l}\text { Execução de testes de estanqueidade } \\
\text { no recebimento de novas tubulações ou } \\
\text { serviços de manutenção. } \\
\text { Implantação de centros de treinamento } \\
\text { e capacitação da mão de obra própria ou } \\
\text { terceirizada. } \\
\text { Implantação de um programa sistemático } \\
\text { de substituição ou restauração da } \\
\text { infraestrutura existente, com base em } \\
\text { diagnóstico de incidências de rupturas e } \\
\text { vazamentos. }\end{array}$ & $\begin{array}{l}\text { Renovação de estrutura que integre } \\
\text { as questões de perdas, garantia do } \\
\text { abastecimento e da qualidade da água. } \\
\text { Utilização de modelos hidráulicos e } \\
\text { mapas temáticos na definição dos trechos } \\
\text { críticos. } \\
\text { Exigência de certificação profissional } \\
\text { para a implantação ou substituição de } \\
\text { estruturas. } \\
\text { Implantação de um programa de gestão } \\
\text { de ativos. }\end{array}$ \\
\hline $\begin{array}{l}\text { Redução de Perdas } \\
\text { Aparentes }\end{array}$ & $\begin{array}{l}\text { Cadastro comercial confiável. } \\
\text { Hidrometração integral das ligaçães. } \\
\text { Conscientização da população para a } \\
\text { questão das fraudes. }\end{array}$ & $\begin{array}{l}\text { Cadastro comercial informatizado. } \\
\text { Gestão da hidrometria, com troca } \\
\text { periódica dos hidrômetros. } \\
\text { Combate às fraudes. } \\
\text { Ações junto às prefeituras para a } \\
\text { regularização de favelas. }\end{array}$ & $\begin{array}{l}\text { Cadastro comercial informatizado e } \\
\text { integrado ao GIS. } \\
\text { Telemetria de grandes consumidores. } \\
\text { Programa otimizado de substituição de } \\
\text { hidrômetros. } \\
\text { Intensificação do combate às fraudes. } \\
\text { Regularização de ligações em favelas. }\end{array}$ \\
\hline
\end{tabular}


Os Programas de Controle de Perdas devem fazer parte do planejamento estratégico (ou qualquer tipo de planejamento) das companhias ou operadoras, ter seus orçamentos definidos e adequados, ser "comprados" pela alta administração e compromissados com todo o corpo funcional da companhia, inclusive as empresas terceirizadas.

\section{AS CRISES HIIDRICAS E AS PERDAS}

Nesses últimos anos, e ainda no momento presente, a região Sudeste do Brasil enfrenta séria crise hídrica, decorrente de precipitações abaixo das médias ou mesmo abaixo das mínimas históricas observadas. Crises hídricas são normais em todo o mundo, em qualquer tempo, e não é prática comum de engenharia prover sistemas de água (ou qualquer outro caso) com "risco zero" para superar impunemente os efeitos dessas crises, pelos elevados custos requeridos. O diferencial reside na forma de fazer a gestão dos recursos hídricos antes e durante as crises.

Obviamente, a questão das perdas nos sistemas de água (especialmente as reais) está inserida no problema e faz parte do conjunto de ações para mitigar os déficits do suprimento de água, com obras ou serviços emergenciais, campanhas para a redução do consumo, penalizações nos casos de consumos abusivos e intensificação do reúso.

As perdas são destacadas na mídia, com profusão de números e gráficos, opinião de especialistas e reportagens mostrando vazamentos (alguns, cinematográficos!) e água limpa escorrendo pelas sarjetas, tentando demonstrar ineficiências da companhia de saneamento e cobrando atuação ágil no reparo dos vazamentos. Essa situação, de fato, exige ações rápidas e que proporcionem resultados em curto prazo na redução das perdas. Assim, daquele conjunto de ações possíveis, devem ser intensificadas, prioritariamente, as seguintes:
- agilidade no reparo dos vazamentos visíveis e não visíveis; no caso de ramais, substituí-los, em vez de repará-los;

- pesquisa de vazamentos não visíveis (detecção acústica);

- redução de pressão (especialmente no período noturno), por meio de regulagens nas VRPs ou boosters, manobras operacionais ou mesmo a implantação de novos equipamentos, onde for possível;

- coibição de fraudes e ligações clandestinas.

A área de engenharia deve lançar mão de tudo que puder para elaborar os diagnósticos e análises, inclusive a modelagem matemática da rede de distribuição (SOARES, 2015). Nesse caso, eventuais substituições de redes que se mostrarem mais adequadas para a redução de vazamentos e a estabilização das pressões ao longo do dia devem ser priorizadas.

Como se sabe, a redução almejada das vazões no sistema de distribuição pode gerar "efeitos colaterais", que vão contra o faturamento e mesmo contra a pretendida redução das perdas. Por exemplo:

- a redução de consumo aumenta a submedição nos hidrômetros (impacto nas finanças da companhia);

- ao longo do processo de redução de consumos, a troca de hidrômetros pode gerar resultados negativos (SOARES, 2015);

- a penalização por consumos excessivos ou mesmo a concessão de bônus para quem reduzir o consumo torna mais "atrativa e compensadora" a execução de fraudes nas ligações.

No caso de a crise se prolongar e for necessário o racionamento de água, as duas soluções possíveis, rodízio no abastecimento e imposição de quota de consumo mensal, são problemáticas no que se refere às perdas, sendo a realização dos rodízios no abastecimento a mais nefasta (CHARALAMBOUS, 2014)! 
É importante ao corpo técnico das companhias, ao vivenciar tal situação transitória de emergência, extrair lições e ensinamentos, que devem ser aplicados posteriormente no dia a dia da operação e manutenção dos sistemas e nas futuras crises.

\section{AS PERDAS NO BRASIL E NO MUNDO}

Além dos dados das próprias empresas ou operadoras de saneamento, as informações sobre os indicadores de perdas no Brasil (entre outras do setor de saneamento) são consolidadas e disponibilizadas anualmente pelo Sistema Nacional de Informações sobre Saneamento (SNIS), do Ministério das Cidades (MC). As variáveis são coletadas em formulário específico e o MC gera os indicadores. As informações são prestadas pelas companhias de saneamento e não são auditadas.

O último relatório disponível do SNIS tem como base o ano de 2013, em que se verifica que a média do indicador de perdas da distribuição no Brasil era de 37\% (SNIS, 2013). Desse relatório, extraiu-se o conteúdo da Tabela 2, com informações sobre as capitais dos estados brasileiros e outras cidades selecionadas. Para não citar somente os indicadores de perdas, colocaram-se também outras importantes informações de contexto, como a população atendida com água, o número de ligações ativas de água, o índice de macromedição e o índice de hidrometração (seria importante também o dado sobre a pressão média do sistema, mas essa informação não está disponibilizada). Os indicadores de perdas apontados referem-se às perdas de faturamento (\%), em que se consideram os volumes faturados (incorporam o faturamento mínimo de $10 \mathrm{~m}^{3} / \mathrm{mês}$, de acordo com regra tarifária), e às perdas na distribuição, em que se consideram os volumes efetivamente micromedidos, em \% e em L/ligação.dia.

Tabela 2 - Dados de perdas de cidades do Brasil - SNIS.

\begin{tabular}{|c|c|c|c|c|c|c|c|c|}
\hline \multirow[b]{2}{*}{ Local } & \multirow[b]{2}{*}{ Operadora } & \multicolumn{4}{|c|}{ Contexto } & \multicolumn{3}{|c|}{ Indicadores de Perdas } \\
\hline & & $\begin{array}{l}\text { AG001 - } \\
\text { População } \\
\text { Atendida } \\
\text { (hab.) }\end{array}$ & $\begin{array}{l}\text { AG002 - } \\
\text { Ligações } \\
\text { Ativas } \\
\left(n^{\circ}\right)\end{array}$ & $\begin{array}{c}\text { IN011 - } \\
\text { Índice de } \\
\text { Macromedição } \\
\text { (\%) }\end{array}$ & $\begin{array}{l}\text { (*) Índice de } \\
\text { Hidrometração } \\
\text { (\%) }\end{array}$ & $\begin{array}{c}\text { IN013 - Índice } \\
\text { de Perdas de } \\
\text { Faturamento } \\
\text { (\%) }\end{array}$ & $\begin{array}{l}\text { IN049 - Índice } \\
\text { de Perdas na } \\
\text { Distribuiç̧ão } \\
\text { (\%) }\end{array}$ & $\begin{array}{c}\text { IN051 - Índice } \\
\text { de Perdas por } \\
\text { Ligação } \\
\text { (L/lig.dia) }\end{array}$ \\
\hline Limeira (SP) & FOZ DE LIMEIRA & 291.748 & 95.710 & 100,0 & 100,0 & 9,4 & 14,5 & 98,7 \\
\hline Lins (SP) & SABESP & 74.366 & 28.472 & 100,0 & 100,0 & 8,0 & 16,4 & 106,1 \\
\hline Franca (SP) & SABESP & 336.734 & 120.670 & 100,0 & 100,0 & 13,2 & 23,7 & 144,5 \\
\hline Maringá (PR) & SANEPAR & 385.753 & 120.139 & 100,0 & 100,0 & 10,9 & 22,5 & 152,8 \\
\hline Goiânia (GO) & SANEAGO & 1.388 .304 & 461.086 & 99,6 & 94,1 & 33,7 & 21,3 & 164,9 \\
\hline $\begin{array}{l}\text { Cach. de } \\
\text { Itapemirim (ES) }\end{array}$ & $\begin{array}{l}\text { FOZDE } \\
\text { CACHOEIRO }\end{array}$ & 205.048 & 52.931 & 94,9 & 99,9 & 12,4 & 23,9 & 169,0 \\
\hline Campinas (SP) & SANASA & 1.119 .836 & 310.426 & 100,0 & 100,0 & 14,9 & 19,2 & 186,2 \\
\hline Blumenau (SC) & $\begin{array}{l}\text { SERVIÇO } \\
\text { AUTÔNOMO }\end{array}$ & 300.006 & 82.097 & 87,1 & 99,9 & 15,1 & 25,3 & 206,4 \\
\hline $\begin{array}{l}\text { Campo Grande } \\
\text { (MS) }\end{array}$ & $\begin{array}{l}\text { ÁGUAS } \\
\text { GUARIROBA }\end{array}$ & 819.012 & 245.317 & 95,9 & 100,0 & 23,8 & 27,7 & 212,8 \\
\hline $\begin{array}{l}\text { Presidente } \\
\text { Prudente (SP) }\end{array}$ & SABESP & 218.960 & 78.021 & 100,0 & 100,0 & 21,1 & 29,3 & 217,0 \\
\hline Petrópolis (RJ) & $\begin{array}{l}\text { ÁGUASDO } \\
\text { IMPERADOR }\end{array}$ & 276.360 & 51.423 & 100,0 & 99,9 & 22,9 & 32,1 & 262,1 \\
\hline Ponta Grossa (PR) & SANEPAR & 331.084 & 101.479 & 100,0 & 100,0 & 24,1 & 38,0 & 262,3 \\
\hline $\begin{array}{l}\text { São Caetano do } \\
\text { Sul (SP) }\end{array}$ & $\begin{array}{l}\text { DEPTO. } \\
\text { MUNICIPAL }\end{array}$ & 156.362 & 36.847 & 99,8 & 100,0 & 21,0 & 19,9 & 264,6 \\
\hline Palmas (TO) & SANEATINS & 232.084 & 83.015 & 100,0 & 100,0 & 27,5 & 35,4 & 266,8 \\
\hline $\begin{array}{l}\text { Feira de Santana } \\
\text { (BA) }\end{array}$ & EMBASA & 554.590 & 148.857 & 100,0 & 98,4 & 30,6 & 47,0 & 293,9 \\
\hline Anápolis (GO) & SANEAGO & 351.145 & 113.737 & 74,3 & 93,3 & 42,7 & 42,7 & 301,7 \\
\hline Brasília (DF) & CAESB & 2.739 .545 & 616.298 & 92,9 & 99,9 & 26,9 & 27,3 & 314,2 \\
\hline
\end{tabular}


Tabela 2 - Dados de perdas de cidades do Brasil - SNIS (continuação).

\begin{tabular}{|c|c|c|c|c|c|c|c|c|}
\hline \multirow[b]{2}{*}{ Local } & \multirow[b]{2}{*}{ Operadora } & \multicolumn{4}{|c|}{ Contexto } & \multicolumn{3}{|c|}{ Indicadores de Perdas } \\
\hline & & $\begin{array}{l}\text { AG001 - } \\
\text { População } \\
\text { Atendida } \\
\text { (hab.) }\end{array}$ & $\begin{array}{l}\text { AG002 - } \\
\text { Ligações } \\
\text { Ativas } \\
\left(n^{\circ}\right)\end{array}$ & $\begin{array}{c}\text { IN011 - } \\
\text { Índice de } \\
\text { Macromedição } \\
\text { (\%) }\end{array}$ & $\begin{array}{c}\text { (*) Índice de } \\
\text { Hidrometração } \\
\text { (\%) }\end{array}$ & $\begin{array}{c}\text { IN013 - Índice } \\
\text { de Perdas de } \\
\text { Faturamento } \\
\text { (\%) }\end{array}$ & $\begin{array}{c}\text { IN049 - Índice } \\
\text { de Perdas na } \\
\text { Distribuição } \\
\text { (\%) }\end{array}$ & $\begin{array}{l}\text { IN051 - Índice } \\
\text { de Perdas por } \\
\text { Ligação } \\
\text { (L/lig.dia) }\end{array}$ \\
\hline $\begin{array}{l}\text { Rondonópolis } \\
\text { (MT) }\end{array}$ & $\begin{array}{l}\text { SERVIÇO } \\
\text { AUTÔNOMO }\end{array}$ & 208.019 & 61.572 & 100,0 & 98,2 & 43,8 & 32,3 & 314,9 \\
\hline Foz do Iguaçu (PR) & SANEPAR & 263.508 & 78.083 & 100,0 & 100,0 & 30,3 & 37,0 & 318,0 \\
\hline Betim (MG) & COPASA & 386.036 & 112.289 & 100,0 & 100,0 & 36,4 & 38,8 & 324,4 \\
\hline Cabo Frio (RJ) & PROLAGOS & 140.733 & 55.426 & 100,0 & 94,4 & 18,4 & 42,7 & 326,1 \\
\hline $\begin{array}{l}\text { Ribeirão Preto } \\
\text { (SP) }\end{array}$ & $\begin{array}{l}\text { DEPTO. } \\
\text { MUNICIPAL }\end{array}$ & 647.713 & 186.110 & 100,0 & 100,0 & 29,7 & 25,0 & 329,0 \\
\hline $\begin{array}{l}\text { São José do Rio } \\
\text { Preto (SP) }\end{array}$ & $\begin{array}{l}\text { SERVIÇO } \\
\text { AUTÔNOMO }\end{array}$ & 4.045 .526 & 124.586 & 100,0 & 100,0 & 26,6 & 32,4 & 331,3 \\
\hline $\begin{array}{l}\text { Juazeiro do Norte } \\
\text { (CE) }\end{array}$ & CAGECE & 244.839 & 79.148 & zero & 99,5 & 33,2 & 46,9 & 336,0 \\
\hline Londrina (PR) & SANEPAR & 537.566 & 154.945 & 100,0 & 100,0 & 28,6 & 35,8 & 336,8 \\
\hline Juiz de Fora (MG) & CESAMA & 534.714 & 125.808 & 92,3 & 100,0 & 28,0 & 34,0 & 339,6 \\
\hline $\begin{array}{l}\text { Campina Grande } \\
\text { (PB) }\end{array}$ & CAGEPA & 400.002 & 115.933 & 95,6 & 99,0 & 39,5 & 40,3 & 346,4 \\
\hline Uberlândia (MG) & $\begin{array}{l}\text { DEPTO. } \\
\text { MUNICIPAL }\end{array}$ & 646.673 & 175.331 & 100,0 & 100,0 & 24,8 & 28,9 & 348,5 \\
\hline Uberaba (MG) & $\begin{array}{l}\text { C. O.DES. E } \\
\text { SANEAMENTO }\end{array}$ & 312.206 & 100.871 & 84,8 & 98,6 & 30,9 & 36,7 & 348,9 \\
\hline $\begin{array}{l}\text { São José dos } \\
\text { Campos (SP) }\end{array}$ & SABESP & 673.255 & 178.550 & 100,0 & 100,0 & 29,9 & 36,0 & 352,5 \\
\hline Caxias do Sul (RS) & $\begin{array}{l}\text { SERVIÇO } \\
\text { AUTÔNOMO }\end{array}$ & 441.471 & 122.461 & 100,0 & 100,0 & 53,5 & 40,1 & 364,4 \\
\hline Fortaleza (CE) & CAGECE & 2.320 .857 & 632.789 & 100,0 & 100,0 & 30,8 & 42,0 & 368,5 \\
\hline Petrolina (PE) & COMPESA & 239.848 & 65.747 & 100,0 & 97,5 & 35,4 & 46,3 & 381,7 \\
\hline Araraquara (SP) & $\begin{array}{l}\text { DEPTO. } \\
\text { MUNICIPAL }\end{array}$ & 216.316 & 89.267 & 90,2 & 100,0 & 39,8 & 39,8 & 399,5 \\
\hline $\begin{array}{l}\text { Novo Hamburgo } \\
\text { (RS) }\end{array}$ & $\begin{array}{l}\text { SERVIÇO } \\
\text { AUTÔNOMO }\end{array}$ & 207.459 & 52.643 & 99,9 & 98,5 & 44,5 & 42,3 & 402,4 \\
\hline Porto Alegre (RS) & $\begin{array}{l}\text { DEPTO. } \\
\text { MUNICIPAL }\end{array}$ & 1.467.816 & 284.582 & 71,1 & 96,2 & 35,7 & 26,3 & 405,3 \\
\hline João Pessoa (PB) & CAGEPA & 733.346 & 185.689 & 87,5 & 95,6 & 40,0 & 39,9 & 407,6 \\
\hline Jundiaí (SP) & DAE & 387.142 & 105.848 & 99,8 & 100,0 & 30,9 & 35,1 & 411,2 \\
\hline Santos (SP) & SABESP & 433.023 & 66.933 & 100,0 & 100,0 & 15,7 & 20,8 & 417,2 \\
\hline Curitiba (PR) & SANEPAR & 1.848 .946 & 464.179 & 100,0 & 100,0 & 30,1 & 39,3 & 418,3 \\
\hline São Paulo (SP) & SABESP & 11.727.298 & 2.851 .875 & 100,0 & 100,0 & 29,2 & 35,8 & 427,0 \\
\hline Santa Maria (RS) & CORSAN & 261.221 & 60.978 & ND & 98,4 & 53,1 & 38,6 & 431,1 \\
\hline $\begin{array}{l}\text { Belo Horizonte } \\
\text { (MG) }\end{array}$ & COPASA & 2.479 .165 & 578.160 & 100,0 & 100,0 & 34,0 & 36,5 & 438,0 \\
\hline Bauru (SP) & $\begin{array}{l}\text { DEPTO. } \\
\text { MUNICIPAL }\end{array}$ & 353.113 & 129.221 & 100,0 & 100,0 & 42,5 & 46,1 & 456,1 \\
\hline Niterói (RJ) & $\begin{array}{l}\text { ÁGUASDE } \\
\text { NITERÓI }\end{array}$ & 494.200 & 87.540 & 100,0 & 89,3 & 15,9 & 26,5 & 465,4 \\
\hline Teresópolis (RJ) & CEDAE & 148.127 & 27.807 & zero & 99,0 & 30,5 & 30,5 & 492,1 \\
\hline $\begin{array}{l}\text { Governador } \\
\text { Valadares (MG) }\end{array}$ & $\begin{array}{l}\text { SERVIÇO } \\
\text { AUTÔNOMO }\end{array}$ & 274.092 & 82.330 & 95,0 & 99,5 & 42,1 & 49,5 & 504,0 \\
\hline Recife (PE) & COMPESA & 1.327 .300 & 306.103 & 97,1 & 87,0 & 37,8 & 49,8 & 513,7 \\
\hline $\begin{array}{l}\text { Volta Redonda } \\
\text { (RJ) }\end{array}$ & $\begin{array}{l}\text { SERVICCO } \\
\text { AUTÔNOMO }\end{array}$ & 261.403 & 75.266 & 92,8 & 99,2 & 40,8 & 40,9 & 524,6 \\
\hline Joinville (SC) & $\begin{array}{l}\text { CIA. ÁGUAS DE } \\
\text { JOINVILLE }\end{array}$ & 538.420 & 137.832 & 100,0 & 100,0 & 40,6 & 47,0 & 569,1 \\
\hline Teresina (PI) & AGESPISA & 776.233 & 241.618 & 89,4 & 95,2 & 48,5 & 53,7 & 578,0 \\
\hline Belém (PA) & COSANPA & 859.595 & 187.547 & 29,3 & 50,8 & 40,7 & 48,1 & 583,7 \\
\hline Florianópolis (SC) & CASAN & 453.285 & 95.104 & 2,9 & 97,4 & 24,6 & 33,7 & 612,8 \\
\hline Vitória (ES) & CESAN & 335.664 & 56.897 & 100,0 & 88,1 & 23,1 & 29,8 & 621,7 \\
\hline Natal (RN) & CAERN & 809.455 & 196.424 & 59,5 & 85,6 & 45,9 & 54,9 & 653,5 \\
\hline Mossoró (RN) & CAERN & 262.780 & 66.894 & 37,9 & 57,6 & 53,7 & 60,6 & 666,2 \\
\hline Boa Vista (RR) & CAER & 301.957 & 77.567 & 58,5 & 66,9 & 53,9 & 54,5 & 673,3 \\
\hline $\begin{array}{l}\text { Quixeramobim } \\
\text { (CE) }\end{array}$ & $\begin{array}{l}\text { SERVICCO } \\
\text { AUTÔNOMO }\end{array}$ & 55.686 & 17.476 & 96,6 & 99,7 & 55,4 & 64,8 & 683,6 \\
\hline Manaus (AM) & $\begin{array}{l}\text { MANAUS } \\
\text { AMBIENTAL }\end{array}$ & 1.641 .405 & 360.249 & 100,0 & 83,2 & 70,2 & 48,2 & 747,2 \\
\hline Aracaju (SE) & DESO & 609.456 & 174.192 & 100,0 & 99,3 & 48,4 & 54,8 & 749,1 \\
\hline Rio de Janeiro (RJ) & CEDAE & 5.874 .342 & 992.693 & 99,5 & 69,2 & 52,1 & 28,5 & 804,3 \\
\hline Salvador (BA) & EMBASA & 2.694 .672 & 502.455 & 93,7 & 92,3 & 50,0 & 52,4 & 841,8 \\
\hline
\end{tabular}


Tabela 2 - Dados de perdas de cidades do Brasil - SNIS (continuação).

\begin{tabular}{|c|c|c|c|c|c|c|c|c|}
\hline \multirow[b]{2}{*}{ Local } & \multirow[b]{2}{*}{ Operadora } & \multicolumn{4}{|c|}{ Contexto } & \multicolumn{3}{|c|}{ Indicadores de Perdas } \\
\hline & & $\begin{array}{l}\text { AG001 - } \\
\text { População } \\
\text { Atendida } \\
\text { (hab.) }\end{array}$ & $\begin{array}{l}\text { AG002 - } \\
\text { Ligações } \\
\text { Ativas } \\
\left(n^{\circ}\right)\end{array}$ & $\begin{array}{c}\text { IN011 - } \\
\text { Índice de } \\
\text { Macromedição } \\
\text { (\%) }\end{array}$ & $\begin{array}{l}\text { (*) Índice de } \\
\text { Hidrometração } \\
\text { (\%) }\end{array}$ & $\begin{array}{c}\text { IN013 - Índice } \\
\text { de Perdas de } \\
\text { Faturamento } \\
\text { (\%) }\end{array}$ & $\begin{array}{l}\text { IN049 - Índice } \\
\text { de Perdas na } \\
\text { Distribuição } \\
\text { (\%) }\end{array}$ & $\begin{array}{l}\text { IN051 - Índice } \\
\text { de Perdas por } \\
\text { Ligação } \\
\text { (L/lig.dia) }\end{array}$ \\
\hline Maceió (AL) & CASAL & 943.410 & 134.839 & 57,4 & 87,5 & 59,5 & 61,3 & 914,5 \\
\hline Rio Branco (AC) & DEPASA & 174.915 & 46.139 & 97,1 & 72,4 & 60,2 & 60,2 & 927,5 \\
\hline São Luís (MA) & CAEMA & 950.147 & 201.350 & zero & 27,5 & 67,2 & 67,2 & $1.272,0$ \\
\hline Cuiabá (MT) & CAB CUIABÁ & 530.095 & 138.645 & 65,0 & 85,1 & 62,9 & 67,3 & $1.289,0$ \\
\hline Porto Velho (RO) & CAERD & 149.244 & 36.428 & zero & 81,4 & 68,9 & 70,3 & $1.709,0$ \\
\hline Macapá (AP) & CAESA & 169.745 & 39.379 & zero & 30,0 & 73,9 & 73,6 & $2.731,0$ \\
\hline
\end{tabular}

(*) AG004(Ligações ativas micromedidas)/AG002(Ligações ativas)

Em termos de expectativas no Brasil, o Plano $\mathrm{Na}-$ cional de Saneamento Básico (PLANSAB) (MINISTÉRIO DAS CIDADES, 2013) propôs metas para o indicador de perdas na distribuição para cada região, conforme mostrado na Tabela 3. Dado o quadro atual do país, é cabível a preocupação se os recursos requeridos para atingir as metas previstas serão adequadamente provisionados.

Tabela 3 - Metas do PLANSAB.

\begin{tabular}{|l|c|c|c|c|}
\hline \multirow{2}{*}{\multicolumn{1}{|c|}{ Região }} & \multicolumn{3}{|c|}{ Metas - Índice de Perdas na Distribuição (\%) } \\
\cline { 2 - 5 } & $\mathbf{2 0 1 0}$ & $\mathbf{2 0 1 8}$ & $\mathbf{2 0 2 3}$ & $\mathbf{2 0 3 3}$ \\
\hline Norte & 51 & 45 & 41 & 33 \\
\hline Nordeste & 51 & 44 & 41 & 33 \\
\hline Sudoeste & 34 & 33 & 32 & 29 \\
\hline Sul & 35 & 33 & 32 & 29 \\
\hline Centro-Oeste & 34 & 32 & 31 & 29 \\
\hline Brasil & 39 & 36 & 34 & 31 \\
\hline
\end{tabular}

Por sua vez, a Tabela 4 reúne informações sobre $o$ indicador de perdas em algumas cidades do mundo (SWAN, 2011; GIESEMANN, 2014; BETTIG, 2012).

\section{CONSIDERAÇÕES FINAIS}

Este trabalho procurou identificar os elementos mais importantes para a qualificação e estruturação de Programas de Controle de Perdas nas redes de distribuição de água, à luz de conceitos e metodologias atualmente em uso.

A grande maioria desses conceitos e metodologias é de desenvolvimento recente, fruto de profícuo trabalho elaborado pela IWA. Às companhias ou operadoras de água, cabe trazer subsídios ao aprimoramento das metodologias, uma vez que

Tabela 4 - Indicadores de perdas de várias cidades do mundo.

\begin{tabular}{|c|c|c|c|c|c|c|c|c|c|}
\hline \multicolumn{10}{|c|}{ Índice de Perdas (\%) } \\
\hline \multicolumn{2}{|c|}{ Até $10 \%$} & \multicolumn{2}{|c|}{ Entre 10 e $20 \%$} & \multicolumn{2}{|c|}{ Entre 20 e $30 \%$} & \multicolumn{2}{|c|}{ Entre 30 e $40 \%$} & \multicolumn{2}{|c|}{ Acima de $40 \%$} \\
\hline Cidade & IP (\%) & Cidade & IP (\%) & Cidade & IP (\%) & Cidade & IP (\%) & Cidade & IP (\%) \\
\hline Melbourne & 3,0 & Milão & 10,4 & Oslo & 22,0 & Guadalajara & 33,7 & Bogotá & 41,0 \\
\hline Copenhague & 4,0 & Madrid & 12,0 & Chicago & 24,0 & Bangcok & 34,0 & Glasgow & 44,0 \\
\hline Singapura & 4,0 & Genebra & 13,7 & Hong Kong & 25,0 & Nairobi & 34,0 & Hanoi & 44,0 \\
\hline Amsterdan & 6,0 & Estocolmo & 15,0 & Santiago & 25,0 & Kuala Lumpur & 35,0 & Bucareste & 46,0 \\
\hline Osaka & 7,0 & Budapeste & 16,5 & Seul & 25,0 & Nápoles & 35,0 & Jakarta & 51,0 \\
\hline Tóquio & 8,0 & Helsinque & 17,0 & Londres & 28,0 & Bangalore & 36,0 & Delhi & 53,0 \\
\hline Viena & 8,5 & Shangai & 17,0 & Istambul & 30,0 & Cid. do México & 37,0 & B. Aires (2) & 43,4 \\
\hline \multirow[t]{5}{*}{ Nova York } & 10,0 & Pequim (1) & 18,0 & & & Lima & 37,0 & & \\
\hline & & Barcelona & 19,0 & & & Roma & 37,8 & & \\
\hline & & Varsóvia & 20,0 & & & São Paulo & 38,0 & & \\
\hline & & & & & & Dublin & 40,0 & & \\
\hline & & & & & & Montreal & 40,0 & & \\
\hline
\end{tabular}


são um perfeito e permanente laboratório em escala 1:1.

Há um longo caminho a percorrer na redução e controle das perdas no Brasil, a despeito de significativos avanços obtidos em várias localidades. Esperam-se progressos pelo setor produtivo (já em curso) na constituição, resistência e trabaIhabilidade das tubulações de água de redes e ramais, bem como na concepção dos medidores de água (afinal, as duas mais importantes "origens" das perdas), além da adequada aplicação desses desenvolvimentos pelas companhias ou operadoras de água e suas subcontratadas.

Para concluir, fica o registro de uma resposta dada pelo engenheiro britânico Allan Lambert, integrante dos grupos de trabalho da IWA e a maior autoridade mundial nas questões ligadas às perdas reais. Perguntado sobre qual a melhor forma de reduzir e controlar as perdas de água e os passos requeridos, ele disse (LAMBERT, 2013):

O primeiro passo é ser honesto e admitir que você tem um problema; daí então começar a quantificar esse problema e priorizar a sequência mais adequada de ações para a situação de cada sistema. Não tenha medo de ouvir e aprender a partir da experiência da sua equipe e de outras pessoas. Não há 'tiro certeiro', nem soluções mágicas, somente progresso gradual obtido por métodos racionais, aplicados por profissionais dedicados, e apoiados por uma administração que verdadeiramente reconhece que a gestão das perdas é uma atividade contínua, e para sempre.

Assim, bem resumido...

\section{REFERÊNCIAS}

ALEGRE, H. et al. Performance Indicators for Water Supply Services, IWA Publishing, Second Edition, 2006

BETTIG, A. P. Estrategias para un Control Eficiente del Agua No Contabilizada - Experiencia AySA; $18^{\circ}$ Congreso Argentino de Saneamiento y Medio Ambiente, 2012

CHARALAMBOUS, B. The Hidden Costs of Resorting to Intermittent Supplies, Lemesos, Cyprus, 2014
COMITÊ DA BACIA DO ALTO TIETÊ/FUSP. Plano da Bacia Hidrográfica do Alto Tietê, São Paulo, 2009

EUROPEAN COMMISSION - Good Practices on Leakage Management - EU Reference Document, 2015

FRAUENDORFER, R. and LIEMBERGER, R. The Issues and Chalenges of Reducing Non-Revenue Water, Asian Development Bank, 2010

GIESEMANN, M. and PING, Z. S. Non-Revenue Water Action Plan for Beijing, IWA Waterloss - 2014, Vienna, 2014

INSTITUTO ARAGONES DE ESTADISTICA. Usos del Agua para Abastecimiento, 2014

KINGDOM, B. et al. The Challenge of Reducing Non-Revenue Water in Developing Countries - How the Private Sector Can Help: A Look at Performance-Based Service Contracting, Banco Mundial, 2006

LAMBERT, A. Don't Be Afraid to Listen to, Learn from Experiences of your Team and Other People (Interview), Water Loss Detectives, n5, March 2013

MINISTÉRIO DAS CIDADES. Plano Nacional de Saneamento Básico - PLANSAB, 2013

RODRIGUES DA COSTA Jr., N. Combate às Perdas de Água - Unidade de Negócio Leste - SABESP. $6^{\circ}$ Encontro Técnico Interamericano de Alto Nível. AIDIS, São Paulo, 2013

SHIMOMURA, M. Sound Management for NRW Control - Turn a Vicious Circle into a Virtuous One, Seminário SABESP, 2013

SILVA Jr., E. G. e CABRAL, R. C. Indicador de Vulnerabilidade da Infraestrutura - Uma Proposta para o Diagnóstico e Tomada de Decisões no Combate às Perdas Reais, Revista Saneas, AESABESP, $n^{\circ} 55$, Abril a Julho de 2015

SNIS - SISTEMA NACIONAL DE INFORMAÇÕES SOBRE SANEAMENTO. Diagnóstico dos Serviços de Água e Esgotos - Base 2013, Ministério das Cidades, 2015

SOARES, D. et al. Desafios na Redução de Perdas de Água Frente à Crise Hídrica na Região Central de São Paulo, Revista Saneas, AESABESP, $n^{\circ}$ 55, Abril a Julho de 2015

SWAN - SMART WATER NETWORKS FORUM. Stated Non Revenue Water Rates in Urban Networks - 2011, 2011

TARDELLI Fo, J. Disponibilidade Hídrica e Controle de Perdas nos Sistemas de Abastecimento de Água da RMSP - SABESP. $6^{\circ} \mathrm{En}-$ contro Técnico Interamericano de Alto Nível. AIDIS, São Paulo, 2013 